\title{
O Quatrilho: da colônia italiana à brasilidade
}

\section{O Quatrilho: from the Italian colony to Brazilianness}

Anderson Hakenhoar Matos ${ }^{1}$

Possui graduação em Licenciatura em Letras (2007) e Mestrado em Letras (2011) pela Universidade Federal do Rio Grande do Sul. Possui experiencia como professor da rede pública e privada na educação básica e técnica. Atualmente e doutorando em Estudos Literátios na Universid

E-mail: hakenhoar@gmail.com
RESUMO: Em O Quatrilho, José Clemente Pozenato retrata a imigração italiana na serra gaúcha e demonstra como a religião teve papel fundamental na manutenção das características dessa comunidade, principalmente no que tange à coletividade. A partir disso, pretende-se demonstrar como esse romance pode ser caracterizado como romance histórico. Além disso, este estudo discute aspectos da identidade cultural do imigrante italiano nesse romance, em especial aqueles que de alguma forma encaminham o imigrante e seus descendentes à brasilidade, a saber, a coletividade (mais propriamente a negação da coletividade) e a influência da religião (neste caso, da religião católica). Para tanto, parte-se das reflexões Lukács (1966), e sua caracterização do romance histórico, de Anderson (2008), e sua concepção de nação como uma comunidade imaginada, e Hall (2009), e suas ideias sobre identidades culturais, para entender a transição da colônia italiana à brasilidade empenhada, sobretudo, por um dos protagonistas da obra em estudo, Ângelo Gardone.

PALAVRAS-CHAVES: Identidade cultural; Imigração italiana; O Quatrilho.

ABSTRACT: In $O$ Quatrilho, José Clemente Pozenato portrays the Italian immigration in the mountains of Rio Grande do Sul and demonstrates how religion played a key role in maintaining the characteristics of that community, especially with regard to collectivity. From this, it is aimed to demonstrate how that novel can be characterized as a historic novel. Besides, this study discusses aspects of the cultural identity of the Italian immigrant in that novel, especially those that somehow lead immigrants and their descendants to Brazilianness, namely collectivity (more precisely the negation of collectivity) and the influence of religion (in this case the Catholic religion). To this end, we start from the reflections of Lukács (1996) and his characterization of historic novel, from Anderson (2008) and his conception of nation as an imagined community, and Hall (2009) and his ideas on cultural identities, to understand the transition from the Italian colony to Brazilianness committed mainly by the protagonists of the work under study, Angelo Gardone.

KEYworDS: Cultural identity; Italian immigration; O Quatrilho. 


\section{Introdução}

rimeira obra da trilogia que trata da imigração italiana no Rio Grande do Sul ${ }^{1}$, O Quatrilho, de José Clemente Pozenato, foi publicada em 1985 e, dez anos depois, adaptada ao cinema por Fábio Barreto. No romance, Pozenato retrata a imigração italiana na serra gaúcha e demonstra como a religião teve papel fundamental na manutenção das práticas sociais e, por que não, individuais dos sujeitos dessa comunidade, principalmente no que tange à coletividade. Lê-se na obra a intrigante história de uma troca casais e dos reflexos que essa prática, ofensiva a Igreja e, por consequência, a coletividade, pode vir a trazer. Essa narrativa tem como pano de fundo a vida de imigrantes italianos e de seus descendentes no Rio Grande do Sul.

José Clemente Pozenato resgata a imagem da colonização italiana no Rio Grande do Sul no romance $O$ Quatrilho. Mesmo não se enquadrando declaradamente na tradição do romance histórico, o panorama sóciohistórico da imigração é construído no texto a partir das forças que atuam no universo das personagens, em especial, da religião. A narrativa dá conta das tradições familiares dos colonos, do distanciamento destes para com os gaúchos (vistos pelo personagem Ângelo Gardone como bandidos), e, principalmente, do papel da religião na manutenção de uma comunidade fechada (pátria imaginária?).

O romance histórico, como define Georg Lukács (1966), é aquele que se caracteriza por revelar forças sociais em disputa. Nessa ótica, a consciência histórica do romancista conta mais do que a representação do passado. É essa consciência que habilita o escritor a conhecer o seu povo e daí chegar ao que Lukács chama de "verdade histórica". É a partir da fórmula consagrada de Lukács (1966) que Frederic Jameson (2007) pensa o romance histórico,

$\overline{1 \text { As outras obras são } A}$ Cocanha (2000) e A Babilônia (2006). mas procurando fugir das armadilhas do discurso marxista de Lukács. Assim, Jameson define o romance histórico como aquele que articula uma oposição entre um plano público ou histórico (definido pelos acontecimentos, crises, costumes) e um plano individual ou existencial, manifestado na categoria narrativa dos personagens. Sua riqueza consiste justamente na qualidade dessa intersecção entre os planos. A diferença entre um romance e um romance histórico está na presença neste último de um grande evento histórico que faça a mediação entre os tempos individuais e o tempo histórico do mundo público. O romance histórico não é, portanto, uma descrição de costumes e valores de um povo em um determinado momento da sua história, nem a representação de eventos históricos ou a história privada de grandes figuras históricas. Jameson afirma que ele pode incluir todos esses aspectos, mas somente sob a condição de que eles tenham sido organizados em uma oposição entre os planos público/histórico e individual/existencial. Entretanto, Jameson reconhece que a prioridade que o modernismo confere à percepção pura, a subjetividade, torna cada vez mais difícil discernir a objetividade da dimensão histórica em relação a todas as subjetividades individuais.

A partir disso, pode-se considerar $O$ Quatrilho um romance histórico, pois Pozenato traz para a literatura a saga dos imigrantes italianos e seus descendentes no Rio Grande do Sul, enfocando as forças sociais que permeiam a sua vida nas colônias. Segundo Rangel (2004), desde as primeiras gerações, até o momento da desintegração do modelo minifundiário familiar, o autor procura mostrar as incongruências, os sacrifícios e a brutalização daquelas pessoas do mundo colonial em sucessão de pequenos dramas. Da mesma forma que Lukács (1966) identifica como característica estruturante do romance histórico dos séculos XVIII a XX os conflitos que marcaram o declínio da sociedade feudal e a conflituosa ascensão e consolidação da civilização burguesa, lemos em $O$ Quatrilho os conflitos que marcam o abandono pelos 
imigrantes e seus descendentes da vida rural no campo rumo à vida burguesa na cidade.

O título do romance faz referência ao jogo de quatrilho, um jogo de cartas comum entre os imigrantes italianos naquele período. Nesse jogo, a cada mão de cartas ocorre a troca de parceiros. Ambientado na região colonial gaúcha de Caxias do Sul, em fins do século XIX, traz como personagens protagonistas os casais Teresa e Ângelo Gardone e Pierina e Mássimo Boschini. Ângelo, Pierina e Teresa são filhos de imigrantes italianos e nasceram no Brasil, embora não se sintam brasileiros. Já Mássimo veio da Itália para encontrar o tio, Padre Giobbe, e fazer sua vida aqui. Esses personagens protagonizam a história de troca de casais.

Um narrador onisciente narra esta história que é dividida em quatro partes: na primeira, conta sobre o casamento de Ângelo Gardone e Teresa, Mássimo Boschini e Pierina e, como pano de fundo, sobre a vida na colônia; na segunda, conta sobre a sociedade formada pelos dois casais, a vida em Caxias do Sul, o trabalho em sociedade na colônia, a vida em comunidade e como a troca de casais iniciou; na terceira, conta sobre a opressão imposta pela Igreja e consequentemente pela comunidade a Ângelo e a Pierina, que foram abandonados por seus pares; por fim, na última parte, temos notícias dos personagens passados alguns anos. $\mathrm{O}$ foco do narrador muda a cada capítulo, de maneira que temos uma noção clara do que pensa e como age cada um dos protagonistas da narrativa.

A narrativa inicia com o casamento de Ângelo Gardone e Teresa, que vai morar na casa da família do marido logo após o fim da cerimônia. Como filho mais velho, diz a tradição que Ângelo deveria deixar as terras da família, que não produziam o suficiente para todos, assim que um de seus irmãos casasse, sendo forçado, então, a procurar novas terras. Quando isso acontece, desprovidos de reservas para adquirir um lote de terra, Ângelo e Teresa se juntam em sociedade a Mássimo e Pierina e vão todos morar na mesma casa.
Após serem abandonados por Mássimo e Teresa, Ângelo e Pierina passam a viver em concubinato e sofrem com as restrições impostas pelo padre local e, por causa disso, deixam de fazer parte da coletividade da colônia italiana e rumam para a brasilidade.

Ao mesmo tempo em que vemos a força da religião católica na vida dos colonos e a importância que ela tem para a manutenção da coletividade, percebemos as contradições que levam os personagens a se afastarem da Igreja e, por conseguinte, da coletividade rumo a uma relação mais próxima com a brasilidade. A partir disso, este estudo se propõe a analisar o papel da religião na manutenção da coletividade da comunidade dos imigrantes italianos na obra citada de Pozenato e de que maneira a não participação nessa coletividade abre caminho para a transição da colônia italiana à brasilidade. Para tanto, parte-se das reflexões de Anderson (2008), e sua concepção de nação como uma comunidade imaginada, e Hall (2009), e suas ideias sobre identidades culturais, para entender a transição da colônia italiana à brasilidade empenhada, sobretudo, por um dos protagonistas da obra em estudo, Ângelo Gardone.

\section{A imigração italiana no Brasil}

A partir da revolução industrial, principalmente, a Europa viveu um intenso processo de industrialização e modernização. No início desse período, na Itália, a população camponesa era de 75 a $90 \%$ da população total, conforme Fávero (2006). Passando de uma economia predominantemente agrária para uma economia industrial, a Itália tem sua sociedade transformada pelo rápido processo de urbanização. Em conseqüência, ocorre a proletarização de numerosa quota de camponeses emigrados para as cidades, compondo uma massa de assalariados urbanos já que, como mão-de-obra, foram destituídos do trabalho na terra. Os trabalhadores que, pelas mais diversas razões, 
não eram absorvidos pela indústria quedavam-se a margem da sociedade, constituindo, conforme Favaro (2006), a grande origem emigratória para outras nações europeias e para outros continentes. A industrialização e o consequente intenso processo de urbanização propiciaram o surgimento do processo emigratório italiano para o Brasil.

No Brasil, a vinda desses imigrantes italianos significava a formação de uma classe trabalhadora não escrava (uma "classe média"), visto que a organização social do país era marcada pela divisão em proprietários de terra e escravos. Além disso, significava a vinda de mão-de-obra onerosa, já que implicava em custos aos grandes proprietários de terra; e, por fim, significava também uma tentativa de branqueamento da sociedade brasileira, conforme Ortiz (2006).

Para Pesavento (2002), a entrada dos imigrantes possibilitou o início do processo de transição de mão-de-obra escrava para a mão-de-obra livre tanto no Brasil quanto nas demais nações latino-americanas que receberam fluxos migratórios. Para a pesquisadora, a vinda dos italianos serviu a dois interesses do centro do país: promover o abastecimento do mercado interno brasileiro gerado pelo complexo cafeeiro e formar núcleos coloniais imigrantes bem sucedidos no sul, para que servissem como ponto de atração à imigração estrangeira para o país.

Desse duplo interesse, resultava que, uma vez chegados no Brasil, muitos imigrantes, que almejavam tornarem-se pequenos proprietários de terra, acabavam sendo desviados para o trabalho nas fazendas de café de São Paulo. Os que eram encaminhados para a região sul tampouco tiveram sorte, já que foram obrigados a embrenharem-se nas matas e a derrubá-las para construir habitação e preparar a lavoura.

No Rio Grande do Sul, as primeiras colônias italianas formaram-se a partir de 1870, Princesa Isabel (atual cidade de Bento Gonçalves) e Conde D’Eu (atual Garibaldi). Esse isolamento foi, ao mesmo tempo, um transtorno para os imigrantes e uma forma de manter sua coletividade, já que o isolamento é o principal estrategema utilizado para preservar a identidade cultural de um povo (GUIBERNAU, 1997).

\section{Da colônia italiana rumo à brasilidade}

O que é uma nação? Benedict Anderson (2008) partiu da diferença entre estado nacional, portanto, político, e a nação propriamente para pensar esta como uma comunidade imaginada. Segundo ele, os estados nacionais, "novos" e "históricos", seriam a expressão política dada a nação, que possui um "passado imemorial" e um "futuro ilimitado". Anderson explica a noção de nação como uma comunidade imaginada, e faz uma analogia com um organismo sociológico atravessando cronologicamente um tempo vazio e homogêneo. A nação é também concebida como uma comunidade sólida que percorre constantemente a história. Um italiano nunca conhecerá e nem sequer saberá o nome da imensa maioria de seus milhões de compatriotas, mas tem confiança na atividade constante, anônima e simultânea deles, atividade que fará com que a nação perdure na história.

O termo "comunidade", em destaque na obra de Anderson, pode ser entendido como um conjunto de habitantes de um mesmo Estado ou qualquer grupo social cujos elementos vivam numa dada área, sob um governo comum e irmanados por um mesmo legado cultural e histórico, ou seja, uma comunidade marcadamente politizada. Mas também induz a pensar a nação como uma coletividade ligada por determinada consciência histórica e/ou por interesses sociais e/ou culturais e/ou econômicos e/ou políticos comuns. Perceba-se que esta coletividade não é política, apesar de poder ser politizada e/ou existir graças a um interesse político comum. Não é política porque não possui estado. Levando em conta essa ideia de nação, como coletividade, pode-se pensar em nações sem estado, como antes já 
pensara Montserrat Guibernau (1997). Guibernau entende a nação como um "grupo humano consciente de formar uma comunidade, partilhando uma cultura comum, ligado a um território claramente demarcado, tendo um passado e um projeto comuns para o futuro, e exigindo o direito de se governar" (1997, p. 110). Compreende-se, a partir do que disso, que uma nação não necessariamente terá um estado, embora possa almejar um.

Por sua vez, a palavra "imaginada" não deixa dúvida da necessidade de uma consciência nacional. Essa consciência visa manter ou manter e recuperar a cultura da coletividade. Desse modo, tem-se um primeiro aspecto relevante para pensar a nação como comunidade imaginada: a consciência nacional de uma coletividade independe de um estado.

Ao tratar da nação como comunidade imaginada, Anderson (2008) faz um estudo a cerca da origem e difusão do nacionalismo e dá relevância para o papel das religiões nesse processo, chegando a ressaltar a grande afinidade do imaginário nacionalista com os imaginários religiosos. Anderson chama atenção para o fato de que os impérios religiosos eram imaginados principalmente pelo uso de uma língua e de uma escrita sagrada, talvez daí a origem da cultura nacional ser vista como enraizada na língua falada e escrita. Tem-se, pois, um segundo aspecto relevante para pensar a nação como comunidade imaginada: a língua como elemento identitário. Pode-se inferir a partir dessa ideia que toda nação, enquanto comunidade imaginada, terá uma língua para expressar sua identidade cultural, e que essa língua será um dos elementos mais marcantes de sua identidade.

Entretanto, a afinidade do imaginário nacionalista com os imaginários religiosos não se detém a língua. Guibernau afirma que "uma nação-estado envolve a criação de um aparelho de estado que controla o uso legítimo dos meios da violência em seu território, conserva soberania interna e externa, e recebe o reconhecimento internacional de sua situação" (1997, p. 126). Pensando uma das funções da nação-estado, o controle da violência em seu território, infere-se que, na ausência de um estado, outras instituições podem assumir esse papel, visto que ao longo da história o controle da violência em um determinado território é fato constante, ao passo que um estado político não é. Seguindo esse raciocínio, o argumento de Anderson (2008) de que os impérios religiosos tinham força suficiente para controlar as massas ilustra bem a afinidade do imaginário nacionalista com os imaginários religiosos. Como exemplo, Anderson afirma que

se o clero transeuropeu letrado em latim era um elemento essencial na estruturação do imaginário cristão, igualmente vital era a transmissão dessas concepções para as massas iletradas, por meio de criações visuais e auditivas, sempre pessoais e particulares (ANDERSON, 2008, p. 52).

Os impérios religiosos necessitavam (e ainda necessitam) também de um aparelho que contivesse a violência para que suas próprias existências fossem viáveis. Como ilustrado por Anderson, no caso da religião católica o principal aparelho era o discurso. Por outro lado, a religião contribuía para a manutenção da coletividade, por meio das práticas que lhes são próprias (rituais, princípios e leis, etc). Para Anderson (2008), foi justamente a coletividade mantida pelas religiões que originou um princípio que chamou de "territorialização dos credos", e exemplifica seu argumento escrevendo sobre o fato de Marco Polo qualificar a fé cristã como "a mais verdadeira" e não "a verdadeira". Tem-se, por fim, um terceiro aspecto relevante para pensar a nação como comunidade imaginada: apesar da decadência de muitos impérios religiosos, o imaginário religioso ainda pode influenciar a manutenção da coletividade.

Pensar uma nação como comunidade imaginada, portanto, requer que se perceba a existência de uma consciência nacional de uma coletividade (o que independe de estado), a língua como um elemento unificador e caracterizador dessa coletividade, e, em muitos casos, a força do imaginário religioso como 
elemento mantenedor da coletividade, em especial, em situações em que não há o poder de um estado. Com base nessas reflexões, cabe refletir, a partir d'O Quatrilho, sobre a imigração italiana no Brasil, em especial no Rio Grande do Sul, que serve como pano de fundo para esta narrativa de Pozenato. Obviamente não se defende a tese de que as colônias de imigrantes italianos que surgiram no Rio Grande do Sul formaram uma comunidade imaginada, no sentido atribuído por Anderson, de nação. O objetivo deste estudo é antes pensar como as personagens d'O Quatrilho rumam para a brasilidade, ou seja, como em terras brasileiras os imigrantes mantêm as marcas de sua coletividade (as marcas de ser italiano) e de que forma deixam de fazer parte dessa coletividade para ingressar em outra, a brasileira.

Ao dispor sobre a origem da nação, Anderson (2008) atribui aos impérios religiosos uma explicação para o surgimento do que chamou de consciência nacional. Nesse ponto, comunidade é entendida como uma coletividade unida por uma consciência nacional. A partir daí, questiona-se: "por que a nação se tornou tão popular dentro desse tipo de comunidade?" (ANDERSON, 2008, p. 71) e conclui que isso de deve em grande parte ao capitalismo. A relação entre imaginário religioso e capitalismo, além dos questionamentos que a aproximação de ambos pode propiciar, é exposta em $O$ Quatrilho, onde se pode perceber que o acesso à propriedade privada permite o acesso de um sujeito a uma comunidade, ou seja, pode torná-lo civilizado, "como todos os outros", pois, nas palavras de Woortmann (1994), a propriedade privada expressa valores familiares e hierárquicos, também defendidos pela igreja cristã.

a noção de patrimônio se distingue daquela de propriedade individual mercantil, pois a terra... não é simplesmente um bem imóvel, e o casamento, se tem uma razão prática, e se é uma estratégia de reprodução material, tem igualmente uma 'razão cultural', pois busca reproduzir uma descendência. A terra é parte de uma ordem moral; mais que objeto de trabalho... ela é o patrimônio de uma 'linhagem'. Sob ambos os pontos de vista, ela expressa o valor: família e hierarquia (WOORTMANN, 1994, p. 311).
Woortmann (1994) enfatiza que a família camponesa é uma instituição importante para a regulamentação do comportamento e da preservação de valores culturais, e mostra como as práticas de sociabilidade, principalmente o parentesco - seja como descendência, seja como casamento -, se relacionam ao patrimônio territorial camponês. A partir disso é possível compreender que tanto o compromisso de Ângelo com a criação dos irmãos, assim como sua expulsão da casa da família quando do casamento do irmão mais novo, quanto a passagem de Mássimo pelo seminário e sua posterior migração, além da valorização do perfil laborioso de Pierina e da possibilidade de ascensão à condição de "mulher" atribuída ao casamento por Teresa, não são meramente "invenção" do autor, mas estão assentados, de algum modo, nas tradições daqueles colonos.

Nesse sentido, é relevante o sonho de Ângelo de ser dono da sua terra, gerando o próprio sustento e não dependendo de um salário pago por outro. É a partir de uma tradição camponesa (possuir uma lavoura) que os casais se associam e acabam tendo que viver sob o mesmo teto, o que tem como consequência a troca de casais e a exclusão da coletividade que buscavam manter seguindo as tradições.

Conforme Lukács (1966), o herói do romance histórico jamais é clássico ou romântico, pois as narrativas giram em torno de personagens ficcionais médias, que emergem de situações de crise; isto é, o herói médio é o homem comum que se torna líder não voluntariamente, mas ao acaso, no emaranhado das complexas relações sociais, o que possibilita reunir em si em si os lados mais marcantes (tanto positivos quanto negativos) de determinado movimento. Assim, o personagem Ângelo Gardone, como homem comum em meio a complexas relações sociais, lidera um movimento de ruptura com a colônia rural e fortemente religiosa em direção à cidade, que representa toda civilização burguesa (na qual sua situação matrimonial é aceitável). Isso significa que todo o complexo de componentes sociais se 
exprime na trama das paixões das personagens protagonistas do romance de Pozenato, ao sabor das incertezas e contradições que lhes são peculiares. Dessa forma, ao abordar a vida dos imigrantes italianos e seus descendentes na região sul do Brasil em direção a uma brasilidade, Pozenato cumpre o que Lukács preconiza como o papel do escritor de romance histórico: "la tarea del escritor consiste en hacerlas [personagens] actuar en tal forma que aparezcan como verdaderos representantes de esas crisis históricas" (1966, p. 40). Por isso, Lukács afirma:

Poco importa, pues, en la novela histórica la relación de los grandes acontecimientos históricos; se trata de resucitar poéticamente a los seres humanos que figuraron en esos acontecimientos. Lo importante es procurar la vivencia de los móviles sociales e individuales por los que los hombres pensaron, sintieron y actuaron precisamente del modo en que ocurrió en la realidad histórica. Y si bien a primera vista pueda parecer paradójico, después de un examen más detenido es evidente que una de las leyes de la plasmación poética consiste en que, para hacer patentes tales móviles humanos y sociales de la actuación, son más apropiados los sucesos aparentemente insignificantes que los grandes dramas monumentales de la historia universal (LUKÁCS, 1966, p. 44).

A partir disso, cada um dos personagens do romance, enquanto "indivíduo histórico-universal", é aqui representante de uma das muitas classes e camadas conflitantes.

Arendt e Pavani (2006) chamam atenção para elementos mantenedores da coletividade presentes em $O$ Quatrilho, que, mais do que unir os indivíduos em comunidade, são a expressão de sua identidade cultural. Os cantos e as danças de origem italiana fazem parte da vida social dos personagens e, por meio do texto literário analisado, ambos concluem que "a manutenção da identidade está nitidamente vinculada a esses elementos” (p. 234). Portanto, as festas, as músicas, as danças, os jogos, as comidas e bebidas típicas, entre outros, permitem partilhar sentimentos coletivos e conhecimentos comunitários nos quais estão incluídos as tradições, os valores morais e as utopias da coletividade que a celebra. Essa característica é legível na narrativa quando do casamento dos personagens Ângelo Gardone e Teresa: "O ruído da festa chegava amortecido. Tirou a tampa de palha do garrafão e encheu a caneca. Lá fora, vozes, cada vez mais fortes, cantavam: Sul ponte di Bassano / Noi ci darêm la mano..." (POZENATO, 1995, p. 23).

Apesar disso, chama a atenção o fato de o personagem Aurélio Gardone, vindo da Itália após o casamento com Rosa, acordar cedo todos os dias para tomar chimarrão. Ao adquirir o hábito de tomar chimarrão, típico entre os habitantes do Rio Grande do Sul, o imigrante italiano está assimilando os costumes locais, tornando-se um sujeito de cultura híbrida, processo que, segundo Seyferth (2004, p. 150), "contém o pressuposto da duplicidade resultante do contato dos imigrantes e seus descendentes com o meio ambiente, a sociedade e a cultura brasileira". Curiosamente, a personagem Teresa, nora de Aurélio, só consegue se aproximar dele quando passa a tomar chimarrão junto com o pai de seu marido. Stuarty Hall explica que

O hibridismo não se refere a indivíduos híbridos, que podem ser contrastados com os 'tradicionais' e 'modernos' como sujeitos plenamente formados Trata-se de um processo de tradução cultural, agonístico uma vez que nunca se completa, mas que permanece em sua indecibilidade (HALL, 2009, p. 71).

Aurélio, assim como todos os imigrantes italianos e seus descendentes, possui uma identidade cultural que o une a todos os demais colonos. Nas palavras de Hall (2009, p. 29), está "em contato com um núcleo imutável e atemporal, ligando ao passado o futuro e o presente numa linha ininterrupta", ou seja, está ligado a uma tradição. É essa tradição, que como mito que é "tem potencial real dos nossos mitos dominantes de moldar nossos imaginários, influenciar nossas ações, conferir significado às nossas vidas e dar sentido à 
nossa história" (HALL, 2009, p. 29), que será questionada e revisada quando do contato com outra tradição, nesse caso, a identidade cultural brasileira, mais especificamente do Rio Grande do Sul. A identidade cultural híbrida resultante desse processo é também um processo histórico, sobre o qual Bhabha esclarece:

Não é simplesmente apropriação ou adaptação; é um processo através do qual se demanda das culturas uma revisão de seus próprios sistemas de referência, normas e valores, pelo distanciamento de suas regras habituais ou 'inerentes' de transformação. Ambivalência e antagonismo acompanham cada ato de tradução cultural, pois o negociar com a 'diferença do outro' revela uma insuficiência radical de nossos próprios sistemas de significado e significação (BHABHA, 1997 apud HALL, 2009, p. 71)

Apesar disso, em $O$ Quatrilho, os colonos têm uma visão dos brasileiros um tanto preconceituosa, como fica evidente no trecho em que Ângelo encontra dois brasileiros, vestidos à moda gaúcha, falando alto e em português, enquanto nenhum dos colonos fala português.

Perto do balcão estavam dois barbudos, de calças largas como saias, enfiadas nas botas, e um xale, furado no meio, metido no pescoço. Falavam alto e riam. Ele nada entendia, não falavam italiano. "Cara de bandidos", pensou, receoso. Um rapaz de avental comprido até os pés chegou a sua mesa. Ângelo pediu um café e perguntou, com voz medrosa:

- Quem são aqueles dois?

- Fazendeiros (...) Criam bois e ovelhas. Têm muitas terras. Não são italianos como nós. São brasileiros (POZENATO, 1995, p. 81).

Os brasileiros são evidentemente julgados por suas vestes, seus modos e por suas posses. Com relação a isso, Ângelo mantém uma atitude de distanciamento devido ao seu preconceito para com os brasileiros, visto que esses não apresentavam os mesmos valores e tradições ("Cara de bandidos", pensa ele); mas com relação a sua situação financeira, grandes proprie- tários de terras, Ângelo se sente inferior. Ao mesmo tempo, não se vislumbra, por parte das personagens, nenhuma identificação para com os brasileiros.

A respeito da manutenção da tradição cultural de seu lugar de origem, o filó tem grande relevância entre os colonos, da mesma forma que a festa, os cantos e as danças; por isso, o filó constitui o que Costa (1998) chama de uma "experiência de paraíso", ou seja, uma oportunidade para troca de experiências, para a ajuda entre as famílias e entre os vizinhos, para orações em grupo, etc. Na Itália, a palavra filó significa "o conjunto de trabalhos manuais que podiam ser executados em casa, no período de inverno" (COSTA, 1998, p. 178), como preparar refeições, costurar, bordar, tricotar, fiar, debulhar milho. Além disso, o filó era o momento em que se contavam histórias, se ensinava aos filhos pequenos a decorar o catecismo e outras orações. Para Arendt e Pavani (2006, p. 234), "o filó, em solo brasileiro, transforma-se também num momento de integração festiva entre as famílias de imigrantes". O filó, prática comuns nas colônias de imigrantes italianos, era uma maneira pela qual as comunidades mantinham certas práticas culturais das suas localidades de origem, tanto no que se refere a hábitos próprios, quanto na manutenção da coletividade, além da prática religiosa.

O filó era, pois, um momento de harmonia da família consigo mesma, da família com Deus através da oração, e da família com os vizinhos, através de encontros periódicos, ditados pelo bom-senso e pelo nível de amizade entre as famílias de costumes e tradições próprias (COSTA, 1998, p. 179).

Em $O$ Quatrilho, é descrito um filó realizado na casa de Ângelo e Teresa, em uma tentativa de Teresa de "amansar os bichos daquela toca selvagem", numa clara expressão de que as pessoas da casa não mantinham muitas relações com outros familiares e com os vizinhos. O filó, portanto, é a 
tentativa de Teresa de reunir a família e os vizinhos em uma coletividade. No filó, são consumidos vinho, vinho quente (quentão), batata-doce, pipoca, jogado o quatrilho, confeccionados o bordado e o crochê, além de trançar palha de trigo, como lê-se no trecho abaixo:

Ângelo e Mássimo, mais o Giácomo e o Agostinho, ficaram por ali, para apreciar o jogo. As mulheres se acomodaram nos bancos em roda do fogolar. Tia Gema tirou da cesta um crochê iniciado e começou a discutir o ponto com a Giulieta [...]. Giulieta mostrou um lencinho que estava bordando, com linha inglesa, comprada em Nova Vicenza. Dosolina se animou e pegou também o seu crochê. Matilde resolveu ajudar Bambina a trançar palha de trigo, para não ficar sem fazer nada. [...] Teresa se levantou e quis saber quem comia pipocas. Havia também batata-doce assando na cinza. Tia Gema era por se comer antes as batatas e, mais tarde, as pipocas. Mas antes desejava saber se não teria que trabalhar, porque filó, na casa dela, era para despalhar e debulhar milho. E quem não trabalhasse ficava proibido de comer e beber (POZENATO, 1995, p. 44).

Arendt e Pavani (2006) afirmam que as orações contribuem para a união das personagens e, assim, a unidade do grupo. Mas, por outro lado, destacam também que "a maioria dos italianos que imigraram para o Brasil trouxe consigo, mais do que sentimentos patrióticos em relação à Itália, uma vontade muito grande de promover sua fé com base nos dogmas da Igreja Católica" (p. 236). Esta afirmação vai ao encontro do que diz o sociólogo Olívio Manfrói (1999, p. 44), para quem "as colônias italianas no Rio Grande do Sul não eram um campo propício para a explosão da italianidade. Elas foram o mais extraordinário e original palco de explosão da catolicidade". Talvez por isso, Carbonera (2008) chame atenção para o fato de que a identidade cultural dos imigrantes italianos em $O$ Quatrilho se manifesta tanto na valorização do trabalho e na coletividade, quanto na religiosidade e na autoridade exercida pelo padre. Esta autoridade já é evidenciada no início da narrativa, quando do casamento de Ângelo Gardone e Teresa:
O celebrante, enfiado na sobrepeliz de linho cru, atropelava palavras e gestos. Estava muito evidente que queria se ver livre daquela cerimônia. A um movimento mais brusco, as rendas da sobrepeliz jogaram ao chão o copo de água benta. 0 padre deixou escapar, em voz baixa, um palavrão, e o noivo avermelhou até a raiz dos cabelos, sentindo-se culpado de estar ali atrapalhando a vida do senhor vigário (POZENATO, 1995, p. 11).

Dessa forma, não apenas as orações, mas também a própria presença do padre entre os imigrantes também é fator importante para a construção da identidade coletiva, visto que sua autoridade, como representante da Igreja (e, conforme a tradição católica, de Deus), reforça o sentimento religioso dos personagens. Nas comunidades italianas, o padre era o responsável, ainda segundo Arendt e Pavani (2006), pela ordem e pela moralidade, com autoridade para ter um domínio tão grande sobre a vida dos colonos, que seus conselhos e seu juízo eram a base até mesmo para as decisões econômicas e comerciais dos colonos, como aparece em $O$ Quatrilho:

Padre Giobbe ouvia, com suficiente atenção, a fala nervosa de Ângelo Gardone, mas a sua mente andava longe. De novo, como se estivesse na Itália, chegavam esses homens ainda jovens querendo saber se estavam certos em deixar o seu pedaço de chão e sair em busca de terra, de esperança, de futuro para os filhos [...] o jovem [...] buscava um conselho. Estava o padre de acordo com a ideia de ir para as colônias novas? (POZENATO, 1995, p. 64-65)

Na mesma obra, lê-se um episódio bastante representativo da autoridade e da influência do padre sobre os colonos. Alguns meses após a fuga de Mássimo e Teresa, Ângelo e Pierina resolvem viver em forma de concubinato. Ao saber disso, o Padre Gentile, responsável pela Igreja de San Giusepe, dispensa Ângelo da diretoria da Igreja por ser "um homem sem família” (idem, p. 185) que não terá o mesmo respeito que tinha antes, impede o casal de frequentar as celebrações e instrui toda a comunidade a não manter nenhum contato com o casal, seja de amizade ou mesmo econômico, isolando completamente 
o casal da coletividade. Nesse episódio, é na estrutura familiar tradicional e em rígidos conceitos de moral que se ampara o poder da Igreja sobre a comunidade de San Giusepe. Com base nesses valores, é inaceitável que Ângelo e Pierina morem juntos, já que ambos ainda continuam e continuarão unidos a Teresa e Mássimo, respectivamente, pelas leis da Igreja Católica. O caso só termina quando Pierina insulta publicamente o Padre Gentile dentro da Igreja, acusando-o de manipular a comunidade contra ela e sua família:

O senhor vai para o inferno. 0 senhor é que é o demônio. [...] Eu também tenho pecados. Eu não digo que não. Mas nunca vi um padre fazer o que o senhor fez. Não tenho medo da sua maldição. 0 senhor é um padre falso. Sabe o que é que eu devia fazer? Devia mijar aqui na sua frente. Não faço isso porque não é o senhor que vai limpar (POZENATO, 1995, p. 192-193).

Após a briga com o Padre, representante de uma instituição que funciona como mantenedora da coletividade, o personagem Ângelo e sua nova mulher, Pierina, deixam de fazer parte da coletividade, e se vêem obrigados a buscar outros meios para a sobrevivência de si e de sua família. Por indicação de Scariot (o único personagem que é verdadeiramente desprovido do imaginário religioso) vai fazer negócios com os brasileiros. Portanto, Ângelo rumou para o contato com a brasilidade por causa da exclusão sua e de sua família da coletividade por influência religiosa em um primeiro momento e, após, pela influência não religiosa de Scariot (cujo apelido, "Scariot", já remete a Judas, aquele que traiu Jesus Cristo e, assim, pode ser entendido como aquele que traiu também a coletividade na qual esteve inserido), que o incita a expandir seus negócios, tendo como consequência a ida de Ângelo Gardone e sua família para a cidade de Caxias.

Scariot é o personagem que faz os demais homens da comunidade de San Giusepe refletir sobre a possibilidade de que a troca de casais tenha sido um "golpe" de Ângelo Gardone, uma ideia genial para acomodar as coisas. Curiosamente, é o único do vilarejo que rejeita a Igreja e que vê o mundo de uma maneira lógica e causal, ao contrário dos homens que, religiosos, ainda mantêm uma visão cristã quase medieval - quando o imaginário religioso cristão "não concebia a história como uma cadeia interminável de causas e efeitos, nem imaginava separações entre passado e presente" (ANDERSON, 2008, p. 53) - e entendem a fuga de Teresa e Mássimo como um castigo divino a Ângelo e Pierina.

No entanto, essa intensa religiosidade não acompanha a transferência para a cidade. Nessa situação, a doutrina imposta pelos padres parece abrandar-se (desde que os fiéis mantenham em dia suas obrigações para com a Igreja, como o dízimo), como fica evidente ao final da narrativa na fala de Padre Gentile: "uma escorregada ou outra não faz mal. Para isso existe a confissão." (POZENATO, 1995, p. 206) Não se quer aqui discutir se essa postura religiosa é adequada ou não, apenas mostrar que, em $O$ Quatrilho, na cidade longe da colônia, até mesmo os representantes da religião cristã parecem precisar se adaptar a satisfação do indivíduo (essencial para um sistema econômico que se baseia no consumo, como ensina Benedict Anderson) e não mais do coletivo.

\section{Considerações finais}

Pedro Santos (2011) aponta que o caminho tomado pelos escritores que se aventuram no romance histórico em sua grande expansão após 1970 (como é o caso de José Clemente Pozenato) é de renovar o gênero sem produzir uma ruptura com o que era produzido no século XIX e no início do século XX. Esse modelo, anteriormente firmado, é a opção dos ficcionistas, não acompanhando o que ocorre em outros países da América Latina ou mesmo em países europeus, onde, segundo Weinhardt (1994) 
e Goulart (2004), o chamado romance histórico moderno é caracterizado por uma constante problematização da história oficial com a proposição de novas versões. Pozenato não problematiza a história oficial da colonização, mas foca no homem comum e em como ele se organiza em meio às disputas sociais nesse processo tão marcante na história do Rio Grande do Sul, cumprindo o papel do romance histórico, conforme entende Lukács (1966).

Os imigrantes italianos quando chegam ao Brasil formam vilarejos (colônias) na tentativa de manter uma identidade cultural - uma tradição - ao mesmo tempo em que mantêm uma proteção mútua (seja física, seja cultural) pela sobrevivência da coletividade. A religião é um dos principais elementos dessa cultura e é também um elemento agrupador, centralizador - a Igreja sempre ocupa o espaço central do vilarejo e, mais tarde, das cidades formadas a partir das colônias de imigrantes católicos - dessa coletividade. À medida que um colono se afasta da religião, se afasta também da coletividade e passa a perder aos poucos sua identidade cultural coletiva, já que não mantém mais as tradições que dão sentido a sua história.

Um dos motivos para esse afastamento é o rompimento dos hábitos sociais e familiares mantido na comunidade, como é o caso dos personagens Ângelo e Pierina, excluídos da coletividade por influência do Padre Gentile após passarem a viver em concubinato. Não mais participante de uma coletividade, o individualismo manifesta-se marcadamente, quando, em $O$ Quatrilho, Ângelo Gardone projeta seus esforços para a satisfação financeira pessoal e de sua família, característica marcante do capitalismo. Fora dessa coletividade, o colono busca meios de sobrevivência e ruma para a brasilidade, ou seja, sai da colônia e entra em contato com o brasileiro na cidade para fazer negócios, já carregando consigo alguns hábitos típicos dos brasileiros, como tomar chimarrão.

\section{Referências}

ANDERSON, Benedict. Comunidades imaginadas: reflexões sobre a origem e a difusão do nacionalismo. São Paulo: Companhia das Letras, 2008.

ARENDT, João Cláudio; PAVANI, Cinara Ferreira. América: a anti-utopia da imigração italiana. In: Conexão - Comunicação e Cultura, UCS, Caxias do Sul, v. 5, n. 9, p. 219-241, jan.-jun. 2006

CARBONERA, Ildo. Trajetórias da narrativa ítalo-brasileira: dove é La cuccagna? Porto Alegre. Tese (Doutorado em Letras) - Universidade Federal do Rio Grande do Sul, 2008.

COSTA, Rovílio. Filó - uma experiência de paraíso. In: MAESTRI, Mário. Nós, os ítalogaúchos. Porto Alegre: Ed. Universidade/UFRGS, 1998.

FÁVARO, Cleci Eulália. Os "italianos": entre a realidade e o discurso. In: BOEIRA, Nelson; GOLIN, Tau (Coord.). História Geral do Rio Grande do Sul. Vol. 2 - Império. Passo Fundo: Méritos, p. 301-319, 2006.

GUIBERNAU, Montserrat. Nações sem Estado. In: Nacionalismos: o estado nacional e o nacionalismo no século XX. Rio de Janeiro: Jorge Zahar Editor, 1997.

HALL, Stuarty. Da diáspora: identidades e mediações culturais. Belo Horizonte: Editora UFMG, 2009.

JAMESON, Frederic. O romance histórico ainda é possível? Tradução de Hugo Mader In: Novos Estudos, São Paulo: CEBRAP, n. 77, p. 185-203, mar. 2007

LUKÁCS, Georg. La novela historica. México: Ediciones Era, 1966.

MANFRÓI, Olívio. Imigração e nacionalismo: Imigração italiana e estudos ítalobrasileiros. Caxias do Sul: Educs, 1999.

MENASCHE, Renata. O Quatrilho: casamento, amor e estratégias de reprodução social camponesa. In: Estudos Sociedade e Agricultura, n. 15, p. 179-193, out. 2000.

ORTIZ, Renato. Cultura brasileira e identidade nacional. São Paulo: Brasiliense, 2006.

PESAVENTO, Sandra Jatahy. História do Rio Grande do Sul. 9. ed. Porto Alegre: Mercado Aberto, 2002

POZENATO, J. Clemente. O Quatrilho. Porto Alegre: Mercado Aberto, 1995

RANGEL, Carlos Roberto da Rosa. Os papéis sociais da mulher na obra O Quatrilho. In Itinerários, Araraquara, n. 22, p. 155-171, 2004. 
GOULART, Cátia Rosana Dias. Uma leitura de A cidade dos padres no contexto do novo discurso ficcional-histórico na América Latina. Dissertação (Mestrado em Letras) Fundação Universidade Federal do Rio Grande, 2004.

SANTOS, Pedro Brum. Literatura e intervenção: romance histórico no Brasil. In: Floema, ano VII, n. 9, p. 283-303, jan.-jun. 2011.

SEYFERTH, Giralda. A ideia de cultura teuto-brasileira: literatura, identidade e os significados da etnicidade. In: Horizontes Antropológicos, Porto Alegre, ano 10, n. 22, p. 149-197, jul.-dez. 2004.

WEINHARDT, Marilene. Considerações sobre o romance histórico. In: Letras, Curitiba, n. 43, Editora da UFPR, p. 49-59, 1994.

WOORTMANN, Ellen. Herdeiros, parentes e compadres: colonos do Sul e sitiantes do Nordeste. São Paulo/Brasília: Hucitec/Ednub, 1995.

Recebido em dezembro de 2015.

Aceito em abril de 2016 . 